\title{
FAKTOR YANG MEMPENGARUHI KEPUTUSAN PETANI \\ DALAM MEMILIH WAKTU PANEN JAGUNG \\ (Kasus Pada Petani Jagung di Kabupaten Serang Provinsi Banten)
}

\author{
Oleh: \\ DIAN ANGGRAENI \\ Fakultas Pertanian UNTIRTA \\ Email: dian.1452Yahoo.c.id
}

\begin{abstract}
Abstrak
Jagung merupakan komoditas pangan kedua setelah padi dan sumber kalori atau makanan pengganti beras disamping itu juga sebagai pakan ternak. Kebutuhan jagung akan terus meningkat dari tahun ke tahun, sejalan dengan peningkatan taraf hidup ekonomi masyarakat dan kemajuan industri pakan ternak. Kasryno (2006), mengemukakan bahwa jagung dapat dimanfaatkan untuk pangan, pakan dan bahan baku industri. Tingginya permintaan untuk jagung tua (pipilan) di daerah Banten, tidak secara langsung mendorong petani untuk melakukan pemanenan jagung tua (pipilan). Fenomena menunjukan masih banyak petani yang melakukan pemanenan jagung muda. Dalam memutuskan untuk memilih waktu panen, terdapat beberapa faktor yang mempengaruhi keputusan tersebut diantaranya umur, pendidikan, pengalaman usahatani, permodalan, luas lahan yang dimiliki petani, faktor harga, serta berkaitan dengan kemudahan uang tunai yang akan diperoleh petani. Penelitian ini bertujuan untuk mengetahui faktor-faktor yang mempengaruhi keputusan petani dalam memilih waktu panen jagung.Metode yang digunakan dalam penelitian ini adalah metode survey. Metode penentuan sampel menggunakan simplerandom sampling dengan total sampel sebanyak 101 petani jagung. Data dianalisis dengan menggunakan regresi logistik. Hasil dari penelitian ini adalah secara simultan faktor umur, pendidikan, pengalaman usahatani, luas lahan, modal, harga dan kemudahan mendapatkan uang tunai berpengaruh secara signifikan terhadap keputusan petani dalam memilih waktu panen jagung. Secara parsial, faktor pengalaman (X3), luas lahan usahatani (X4), modal (X5), harga(X6) dan kemudahan mendapatkan uang tunai(D), berpengaruh nyata terhadap keputusan petani dalam memilih waktu panen jagung, sedangkan faktor umu(X1) dan faktor pendidikan (X2) berpengaruh tidak signifikan terhadap keputusan petani dalam memilih waktu panen jagung.
\end{abstract}

Kata kunci: keputusan petani, faktor yang mempengaruhi, jagung

\section{PENDAHULUAN}

Jagung merupakan komoditas pangan kedua setelah padi dan sumber kalori atau makanan pengganti beras disamping itu juga sebagai pakan ternak. Kebutuhan jagung akan terus meningkat dari tahun ke tahun, sejalan dengan peningkatan taraf hidup ekonomi masyarakat dan kemajuan industri pakan ternak. Kasryno (2006), mengemukakan bahwa jagung dapat dimanfaatkan untuk pangan, pakan dan bahan baku industri. Jagung menjadi salah satu komoditas pertanian yang sangat penting dan saling terkait dengan industri besar.Selain untuk konsumsi, untuk sayuran, buah jagung juga bisa diolah menjadi aneka makanan.Selain itu pipilan keringnya dimanfaatkan untuk pakan ternak.

Secara umum kegunaan jagung dapat dikelompokan menjadi : (1) bahan pangan, yang merupakan konsumsi sehari-hari masyarakat Indonesia; (2). Bahan pakan ternak, dan digunakan sebagai pakan utama; (3). Bahan baku industri, yang meliputi industri skala rumah tangga hingga industri besar.Penggunaan komoditas jagung lebih didominasi untuk bahan baku utama induatri pakan ternak yaitu sebesar 51 persen. Selanjutnya diikuti penggunaan bahan pangan antara lain pangan langsung, bahan baku minyak nabati non kolesterol, tepung jagung dan makanan kecil,. Sehingga dalam pengembangannya harus melihat potensi dan struktur kebutuhan secara komprehensip (Direktur Jenderal Kementrian Pertanian, 2010)

Banten adalah salah satu provinsi yang merupakan daerah pengembangan jagung, karena memiliki agroekosistem yang cocok untuk budidaya komoditas tersebut. Komoditas jagung telah dijadikan unggulan oleh Propinsi Banten pada sub sektor tanaman pangan. Terjadinya fluktuasi produksi jagung di Banten disebabkan oleh adanya perbedaan luas panen usahatani. Faktor lain yang menyebabkan rendahnya produksi jagung di Provinsi Banten, diantaranya penggunaan input produksi yang 


\section{MIMBAR \\ Agribisnis}

ISSN 2460-4321

Volume 1・Nomor 1・Juli 2015

belum optimal, teknologi budidaya yang masih sederhana, atau penggunaan benih yang tidak berkualitas, serta perilaku dan kebiasaan petani (Khaerizal,2008).

Bertambahnya pabrik pakan ternak yang ada di Propinsi Banten menyebabkan tidak seimbangnya antara permintaan (demand) dengan penawaran (Supply) jagung.Permintaan pakan ternak tiap tahun 28 juta ton. Sedangkan Propinsi Banten hanya menghasilkan jagung 29.000 ton pada tahun 2010. Kekurangan pasokan bahan baku tersebut dipenuhi dari Sulawesi Selatan, Gorontalo, Jawa Tengah, Jawa Timur dan Lampung. Dengan adanya peningkatan permintaan khususnya dari pabrik pakan ternak tersebut, maka pengembangan dan strategi peningkatan produksi jagung tersebut khususnya di Provinsi Banten sangat penting untuk dilakukan.

Tingginya permintaan untuk jagung tua (pipilan) di daerah Banten, tidak secara langsung mendorong petani untuk melakukan pemanenan jagung tua (pipilan). Fenomena di lapangan masih banyak petani yang melakukan pemanenan jagung muda, hal ini disebabkan oleh beberapa alasan, sesuai yang diungkapkan Suharno (2010), bahwa terdapat beberapa alasan petani melakukan panen jagung muda diantaranya : usia cukup pendek, dapat dipanen mulai umur 60 hari setelah tanam, jagung muda dapat digunakan sebagai bahan baku industri makanan, pemasarannya cukup lancar, dan bisa panen 3 kali dalam setahun. Dalam memutuskan untuk memilih waktu panen, terdapat beberapa faktor yang diduga mempengaruhi keputusan tersebut diantaranya umur, pendidikan, pengalaman usahatani, permodalan, luas lahan yang dimiliki petani, faktor harga, serta berkaitan dengan kemudahan uang tunai yang akan diperoleh petani.

Umur seorang petani sangat berkaitan dengan pola perilaku petani dalam berusahatani, semakin tua usia seseorang, biasanya semakin bijak dalam mengambil keputusan. Sesuai yang diungkapkan Feaster (1983), bahwa tindakan yang diambil seseorang yang berumur lebih tua, dapat dilakukan terencana, sehingga akan membawa hasil yang lebih baik dan sempurna.

Pendidikan memiliki pengaruh terhadap penentuan waktu panen suatu komoditas. Hasyim (2006), mengatakan bahwa tingkat pendidikan formal yang dimiliki petani akan menunjukan tingkat pengetahuan serta wawasan yang luas untuk petani menerapkan apa yang diperolehnya untuk peningkatan usahataninya.

Pengalaman dalam berusahatani memiliki pengaruh dalam penentuan jenis usaha yang akan dilakukan bahkan dalam proses pemanenan komoditas bersangkutan. Pengalaman dalam hal ini berkaitan dengan lamanya waktu yang dicurahkan petani untuk berusahatani. Pengalaman memiliki pengaruh dalam penentuan waktu panen sebab sesuai yang diungkapkan (Hasyim,2006), bahwa lamanya berusahatani dapat dijadikan bahan pertimbangan agar tidak melakukan kesalahan yang sama sehingga dapat melakukan hal yang lebih baik untuk waktu berikutnya. Dengan demikian petani yang sudah berpengalaman cenderung akan mengambil keputusan yang benar dalam memilih waktu panen.

Modal memiliki pengaruh terhadap keputusan petani dalam memilih waktu panen. Pada kenyataan di lapangan tidak semua petani memiliki modal yang cukup tinggi. Aksesibilitas petani terhadap sumber permodalan masih sangat terbatas, terutama bagi petani yang berlahan sempit yang merupakan komoditas terbesar masyarakat pedesaan, sehingga banyak ditemui bahwa kekurangan modal merupakan kendala yang menjadi penghambat bagi petani dalam mengelola usahataninya. Dengan demikian besar kecilnya modal yang dimiliki petani sangat menentukan keputusan mereka dalam memilih waktu panen.

Luas lahan usahatani memiliki pengaruh terhadap keputusan petani.Luas lahan yang digunakan petani akan memiliki pengaruh langsung terhadap biaya dan modal yang harus dikeluarkan petani, dengan demikian luas lahan memiliki pengaruh dalam pengambilan keputusan.

Kemudahan dalam mendapatkan uang tunai, berkaitan dengan lamanya umur tanaman. Tanaman yang berumur pendek memiliki dampak terhadap mudahnya petani untuk memperoleh pendapatan, dan sebaliknya. Pendeknya umur tanaman berkaitan juga dengan siklus pergiliran tanaman yang lebih cepat, sehingga petani akan lebih mudah dan cepat untuk memperoleh pendapatan dan sebaliknya, Fiddiani (2010). Dengan demikian kemudahan mendapatkan uang tunai 


\section{Faktor Yang Mempengaruhi Keputusan Petani dalam Memilih Waktu Panen Jagung \\ (Kasus Pada Petani Jagung di Kabupaten Serang Provinsi Banten) \\ DIAN ANGGRAENI}

mempengaruhi petani dalam mengambil keputusan memilih waktu panen.

Tingginya harga suatu komoditas akan berdampak positif terhadap peningkatan pendapatan petani, dengan demikian faktor harga bisa mempengaruhi keputusan petani dalam penentuan waktu panen jagung. Sesuai penelitian Nunun (2012), bahwa selain faktor pendapatan, faktor harga di tingkat petani sangat mempengaruhi keputusan petani dalam mengusahakan suatu usahatani.

\section{METODE PENELITIAN}

Penelitian dilakukan di Kabupaten Serang Provinsi Banten, dengan waktu penelitian pada Musim Tanam kedua bulan Agustus 2013.

Data yang dipergunakan merupakan data primer dan data sekunder. Data primer diperoleh dengan teknik wawancara langsung terhadap petani jagung yang mengacu pada kuesioner yang telah disiapkan. Sedangkan data sekunder diperoleh dengan cara menelaah laporan hasil penelitian terdahulu, laporan dari instansi terkait, maupun publikasi lain yang relevan.

Sampel ditentukan dengan cara multistage cluster random sampling, dengan tiga tahapan. Tahap pertama menentukan Kecamatan sebagai sentra komoditas jagung. Tahap kedua memilih desa yang dijadikan sebagai secondary sampling unit (SSU) dan tahap tiga memilih petani sebagaisampel dalam penelitian ini dengan menggunakan simple random sampling.

Untuk menentukan faktor yang mempengaruhi keputusan petani dalam memilih waktu panen menggunakan regresi logistik.

\section{HASIL DAN PEMBAHASAN}

\section{Faktor yang Mempengaruhi petani dalam} Memilih Waktu Panen

Secara simultan faktor umur, pendidikan,pengalaman, luas lahan, modal, harga, dan kemudahan untuk mendapatkan uang tunai mempengaruhi keputusan petani dalam memilih waktu panen. Sedangkan secara parsial faktor-faktor tersebut dapat dijelaskan sebagai berikut :

1. Umur

Diduga bahwa faktor umur akan mempengaruhi keputusan petani dalam memilih waktu panen jagung. Dari hasil uji statistik dapat dijelaskan bahwa faktor umur berpengaruh tidak signifikans terhadap keputusan petani dalam memilih waktu panen jagung.

Koefisien pengaruh umur terhadap keputusan memilih waktu panen adalah positif, artinya semakin tua umur petani, maka semakin tinggi atau semakin banyak petani yang melakukan sistem panen tua dibandingkan dengan panen muda.

Nilai Odd Ratio 1,142 artinya jika umur semakin tua, maka peluang petani untuk memilih panen tua 1,142 kali daripada memilih panen muda.Dengan demikian peluang untuk memilih waktu panen tua, lebih besar daripada memilih panen muda seiring dengan semakin tuanya umur di tingkat petani.

Umur merupakan salah satu faktor yang mempengaruhi keberhasilan suatu usahatani.Umur dapat mempengaruhi kemampuan fisik, pengambilan keputusan dan kinerja petani dalam menjalankan usahataninya. Semakin tua umur petani, akan semakin banyak pengalaman yang dia peroleh dan mempunyai kebiasaan yang sulit diubah, sehingga berpengaruh besar terhadap proses adopsi inovasi.

Sesuai yang diungkapkan Kartasapoetra (1994), bahwa petani yang berusia lanjut sekitar 50 tahun ke atas, biasanya fanatik terhadap tradisi dan sulit untuk diberikan pengertian yang dapat mengubah cara berfikir, cara kerja, dan cara hidupnya, mereka biasanya bersikap apatis terhadap adanya teknologi baru.

2. Pendidikan

Diduga bahwa faktor pendidikan akan mempengaruhi keputusan petani alam memilih waktu panen jagung. Dari hasil pengujian dapat dijelaskan bahwa faktor pendidikan berpengaruh tidak signifikans terhadap keputusan petani dalam memilih waktu panen jagung.

Koefisien pengaruh pendidikan terhadap keputusan petani adalah positif artinya, semakin tinggi pendidikan maka, semakin tinggi pula petani yang melakukan sistem panen tua (pipilan).Nilai Odd Ratio 1,312 artinya jika pendidikan semakin tinggi, maka peluang petani untuk memilih waktu panen tua (pipilan) 1,312 kali daripada memilih waktu panen muda.Dengan demikian peluang untuk memilih waktu panen tua, lebih besar daripada memilih panen muda seiring dengan semakin tingginya tingkat pendidikan. 


\section{AIMBAR \\ Agribisnis}

ISSN 2460-4321

Volume 1・Nomor 1・Juli 2015

Pendidikan yang dimaksud dalam penelitian ini adalah pendidikan formal. Pendidikan merupakan faktor yang penting dalam usaha meningkatkan kecerdasan dan keterampilan seseorang.Pendidikan dapat mempengaruhi seseorang terhadap penguasaan pengetahuan, keterampilan,kemampuan mengambil keputusan dan berani mengambil resiko.

Tidak berpengaruhnya pendidikan disebabkan oleh data variabel tersebut yang kurang variasi (variasinya relatif homogen).Tingkat pendidikan para petani jagung sebagian besar tamatan sekolah dasar. Hal ini juga disebabkan mereka yang berpendidikan tinggi secara langsung kemauannya untuk bekerja di sektor pertanian sangat rendah. Bekerja di sektor pertanian merupakan pilihan terakhir setelah pegawai negeri, swasta atau bisnis lainnya.

3. Pengalaman

Diduga bahwa faktor pengalaman dalam berusahatani jagung akan mempengaruhi keputusan petani alam memilih waktu panenjagung. Dari hasil pengujian dapat dijelaskan bahwa faktor pengalaman berpengaruh signifikans terhadap keputusan petani dalam memilih waktu panen jagung.

Koefisien pengaruh pengalaman berusahatani terhadap keputusan petani adalah negatif artinya, semakin lama pengalaman dalam berusahatani jagung, maka, semakin sedikit petani yang melakukan sistem panen tua (pipilan) dan sebaliknya.

Nilai Odd Ratio 0,838, artinya jika pengalaman berusahatani semakin tinggi, maka peluang petani untuk memilih waktu panen tua (pipilan) 0,838 kali daripada memilih waktu panen muda. Dengan demikian peluang untuk memilih waktu panen tua, lebih kecil daripada memilih panen muda seiring dengan lamanya pengalaman dalam berusahatani jagung dan sebaliknya.

Pengalaman dalam berusahatani sangat penting dalam pengelolaan usahatani, baik dalam pengambilan keputusan, penentuan komoditas yang akan diusahakan, maupun dalam penggunaan faktor produksi. Secara umum semakin lama pengalaman dalam berusahatani, kecenderungan semakin efisien dalam penggunaan faktor produksi. Semakin bertambah pengalaman dalam hitungan tahun, maka akan meningkatkan kemampuan dalam aktivitas usahanya, dengan bertambahnya pengalaman pula seorang petani akan mampu lebih cepat beradaptasi terhadap segala bentuk persoalan dan pemecahannya, artinya semakin berambah pengalaman usaha, seorang petani mampu memanage usahanya dengan semakin baik sehingga lambat laun seiring perubahan usia dan pengalaman berusaha akan memupuk kemampuan petani kearah yang lebih baik

Menurut Djatmiko Danuhadimedjo (1998), pengalaman adalah guru yang paling baik, seorang wirausaha harus bercermin pada pengalaman masa lampau dan selalu mempelajarinya guna mendapatkan hasil yang lebih baik lagi. Belajar dari pengalaman masa lampau merupakan kunci keberhasilan.

4. Luas lahan Usahatani

Diduga bahwa faktor luas lahan usahatani akan mempengaruhi keputusan petani dalam memilih waktu panen jagung. Dari hasil pengujian dapat dijelaskan bahwa faktor luas lahan berpengaruh signifikans terhadap keputusan petani dalam memilih waktu panen jagung.

Koefisien pengaruh luas lahan terhadap keputusan petani adalah positif artinya, semakin luas lahan yang dimiliki petani, maka semakintinggi pula petani untuk melakukan sistem panen tua (pipilan).

Nilai Odd Ratio 2493,455 artinya jika luas lahan semakin luas, maka peluang petani untuk memilih waktu panen tua (pipilan) 2493,455 kali daripada memilih waktu panen muda.Dengan demikian peluang untuk memilih waktu panen tua, lebih besar daripada memilih panen muda seiring dengan semakin luasnya penguasaan lahan di tingkat petani.

5. Modal

Diduga bahwa faktor modal akan mempengaruhi keputusan petani alam memilih waktu panen jagung. Dari hasil analisis dapat dijelaskan bahwa faktor modal berpengaruh signifikan terhadap keputusan petani dalam memilih waktu panen jagung.

Koefisien pengaruh modal terhadap keputusan petani adalah positif artinya, semakin tinggi modal maka, semakin tinggi pula petani yang melakukan sistem panen tua (pipilan) dan sebaliknya.

Nilai Odd Ratio 1,000 artinya jika modal semakin tinggi, maka peluang petani untuk 


\section{Faktor Yang Mempengaruhi Keputusan Petani dalam Memilih Waktu Panen Jagung \\ (Kasus Pada Petani Jagung di Kabupaten Serang Provinsi Banten) \\ DIAN ANGGRAENI}

memilih waktu panen tua (pipilan) 1,000 kali daripada memilih waktu panen muda.Dengan demikian peluang untuk memilih waktu panen tua, lebih besar daripada memilih panen muda seiring dengan semakin tingginya modal yang dimiliki petani.

Dalam proses pemanenan jagung tua lebih banyak diperlukan tenaga kerja, selain itu waktu yang diperlukan juga lebih lama dibanding sistem panen muda karena ada proses penanganan pasca panen yaitu pemipilan dan penjemuran, dengan demikian proses pemanenan jagung tua lebih banyak memerlukan modal dibanding sistem panen muda. Jadi sistem pemanenan jagung tua cenderung dilakukan oleh petani yang memiliki modal lebih banyak.

6. Harga

Diduga bahwa faktor harga akan mempengaruhi keputusan petani dalam memilih waktu panen jagung. Dari hasil analisis dapat dijelaskan bahwa faktor harga berpengaruh signifikan terhadap keputusan petani dalam memilih waktu panen jagung.

Koefisien pengaruh harga terhadap keputusan petani adalah positif artinya, semakin tinggi harga jagung, maka semakin tinggi pula petani yang melakukan sistem panen tua (pipilan).

Nilai Odd Ratio 1,004 artinya jika harga jagung semakin mahal atau tinggi, maka peluang petani untuk memilih waktu panen tua (pipilan) 1,004 kali daripada memilih waktu panen muda.Dengan demikian peluang untuk memilih waktupanen tua, lebih besar daripada memilih panen muda seiring dengan semakin tingginya harga jagung di tingkat petani.

Harga suatu output sangat berhubungan dengan penerimaan yang akan diperoleh petani. Dengan harga output yang tinggi, asumsi harga input tetap, maka keuuntungan yang yang diperoleh petani semakin tinggi pula

7. Kemudahan Mendapatkan Uang Tunai

Diduga bahwa faktor kemudahan untuk mendapatkan uang tunai akan mempengaruhi keputusan petani dalam memilih waktu panen jagung. Dari hasil analisis dapat dijelaskan bahwa faktor kemudahan mendapatkan uang tunai berpengaruh signifikans terhadap keputusan petani dalam memilih waktu panen jagung.

Koefisien pengaruh kemudahan untuk mendapatkan uang tunai terhadap keputusan petani adalah negatif artinya, semakin tinggi keinginan petani untuk mendapatkan kemudahan uang tunai, maka semakin sedikit petani yang melakukan sistem panen tua, dan sebaliknya.

Nilai Odd Ratio 0,004, artinya jika keinginan untuk mendapatkan kemudahan uang tunai semakin tinggi, maka peluang petani untuk memilih waktu panen tua (pipilan) 0,004 kali daripada memilih waktu panen muda. Dengan demikian peluang untuk memilih waktu panen tua, lebih kecil daripada memilih panen muda seiring dengan semakin tingginya keinginan petani untuk mendapatkan kemudahan uang tunai.

Perbedaan utama antara sistem panen muda dengan panen tua (pipilan) adalah dari aspek waktu dan penanganan pasca panen. Untuk panen muda cenderung lebih cepat, sehingga petani akan lebih mudah dan cepat untuk mendapatkan uang tunai dari hasil penjualan jagung tersebut. Sebaliknya petani yang melakukan sistem panen tua, untuk mendapatkan uang dari hasil penjualan jagung tersebut relatif lebih lama dengan selisih waktu satu bulan.Dengan demikian petani yang ingin mendapatkan uang tunai lebih cepat atau mudah cenderung banyak melakukan sistem panen muda.

\section{PENUTUP}

Terdapat 7 faktor yang mempengaruhi keputusan petani dalam memilih waktu panen jagung diantaranya adalah umur, pendidikan, pengalaman, luas lahan usahatani, modal, harga dan kemudahan mendapatkan uang tunai.

Secara parsial, faktor pengalaman (X3), luas lahan usahatani (X4), modal (X5), harga(X6) dan kemudahan mendapatkan uang tunai(D), berpengaruh nyata terhadap keputusan petani dalam memilih waktu panen jagung.

\section{DAFTAR PUSTAKA}

Anwas Adiwilaga. 1992. Ilmu Usahatani. Cetakan ke-III. Alumni, Bandung

Hernanto, Fadholi.1985. Ilmu Usahatani. Penebar Swadaya, Jakarta.Kasim,A.1995. Teori Pembuatan Keputusan. Jakarta. Fakultas Ekonomi Universitas Indonesia.

Mangkusubroto,K dan L.Trisnadi.1987. Analisis Keputusan Pendekatan Sistemdalam Manajemen Usaha dan Proyek. Bandung.Ganesa Exact. 


\section{AIMBAR \\ Agribisnis \\ ISSN 2460-4321}

Volume 1・Nomor 1・Juli 2015

Mohamad Nazir. 1988. Metode Penelitian.

Ghalia Indonesia, Jakarta.

Mubyarto. 1989. Pengantar Ekonomi Pertanian. Lembaga Penelitian, Pendidikan dan Penerangan ekonomi dan Sosial (LP3ES) Edisi ke-3. Jakarta

Purwatiningdyah, D.N., 2003. Faktor Internal dan Ekternal Yang Mempengaruhi Tingkat Penerapan Teknologi dan Dampaknya Terhadap Produktivitas dan Pendapatan pada Usahatani Padi Sawah. Bandung. Tesis tidak dipublikasikan. Program Pasacasarjana Universitas Padjadjaran, Bandung.

Singarimbun, M. dan S. Effendi. 1989. Metode Penelitian Survei. LP3ES, Jakarta.

Sukirno,S. 2000. Pengantar Teori Mikro Ekonomi. Raja Grafindo Persada. Jakarta

Teken, Sofyan Asnawi, 2002. Teori Ekonomi Mikro, Bogor, IPB

Thohir, K.A. 1967. Seuntai Pengetahuan Tentang Usahatani Indonesia, Jakarta. Bina Aksara.

Kasryno, F. 2006. Suatu Penilaian Mengenai Prospek Masa Depan Jagung di Indonesia. Makalah disampaikan pada Seminar dan Lokakarya Nasional Jagung, 29-30 September 2006. Balai Penelitian Tanaman Serealia. Maros 